\title{
Targeting PI3K/mTOR signaling in cancer
}

\author{
Alexandre Arcaro* \\ ${ }^{*}$ Correspondence: alexandre.arcaro@dkf.unibe.ch \\ Edited and reviewed by: \\ Paolo Pinton, University of Ferrara, Italy \\ Keywords: Akt, cancer, clinical trials, mTOR, phosphoinositide 3-kinase
}

Department of Clinical Research, Division of Pediatric Hematology/Oncology, University of Bern, Bern, Switzerland

The phosphoinositide 3-kinase (PI3K)/mammalian target of rapamycin (mTOR) pathway is very frequently activated in human cancer by a variety of genetic and epigenetic events. This pathway is thought to contribute to many of the hallmarks of cancer and a large array of agents targeting its key components are currently undergoing clinical testing in cancer patients. In addition to rapamycin analogs ("rapalogs"), which are approved for the treatment of multiple cancers, PI3K inhibitors are likely to be soon approved for B-cell malignancies $(1,2)$.

In this research topic, we have assembled a collection of articles describing recent key aspects of the role of the $\mathrm{PI} 3 \mathrm{~K} / \mathrm{mTOR}$ pathway in cancer and the development of targeted therapies.

Martini et al. review the role of the different classes of PI3K isoforms as targets in oncology (3). Tzenaki and Papakonstanti focus on the role of the PI3K isoform p1 $10 \delta$ in cancer (4). The role of the PI3K/mTOR pathway in cell cycle progression and metabolism is discussed by Vadlakonda and colleagues (5-7). Pardo and Seckl present an overview of $\mathrm{S} 6 \mathrm{~K} 2$, the p70 ribosomal S6 kinase homolog (8).

Porta and colleagues present an up to date overview of the development of selective inhibitors of Akt, mTOR, and PI3K with a focus on the latest clinical trials (9). Weigelt and Downward review the genetic determinants of response to these targeted agents (10). Fox et al. discuss the potential of co-targeting PI3K and the estrogen receptor (ER) in breast cancer (11).

\section{ACKNOWLEDGMENTS}

Work in the author's laboratory is supported by grants from the European Union FP7 (ASSET, project number: 259348 and LUNGTARGET, project number: 259770), the Swiss National Science Foundation (Grant 31003A-146464), the Fondation FORCE, the Novartis Stiftung für Medizinisch-Biologische Forschung, the Jubiläumsstiftung der Schweizerischen Mobiliar Genossenschaft, the Stiftung zur Krebsbekämpfung, the Huggenberger-Bischoff Stiftung zur Krebsforschung, the UniBern Forschungsstiftung, the Stiftung für klinisch-experimentelle Tumorforschung, Bern and the Berner Stiftung für krebskranke Kinder und Jugendliche.

\section{REFERENCES}

1. Furman RR, Sharman JP, Coutre SE, Cheson BD, Pagel JM, Hillmen P, et al. Idelalisib and rituximab in relapsed chronic lymphocytic leukemia. $N$ Engl J Med (2014) 370:997-1007. doi:10.1056/NEJMoa1315226

2. Gopal AK, Kahl BS, De Vos S, Wagner-Johnston ND, Schuster SJ, Jurczak WJ, et al. PI3Kdelta inhibition by idelalisib in patients with relapsed indolent lymphoma. N Engl J Med (2014) 370:1008-18. doi:10.1056/NEJMoa1314583

3. Martini M, Ciraolo E, Gulluni F, Hirsch E. Targeting PI3K in cancer: any good news? Front Oncol (2013) 3:108. doi:10.3389/fonc.2013.00108

4. Tzenaki N, Papakonstanti EA. p110d PI3 kinase pathway: emerging roles in cancer. Front Oncol (2013) 3:40. doi:10.3389/fonc.2013.00040

5. Vadlakonda L, Dash A, Pasupuleti M, Anil Kumar K, Reddanna P. Did we get pasteur, warburg and crabtree on a right note? Front Oncol (2013) 3:186. doi:10.3389/fonc.2013.00186

6. Vadlakonda L, Dash A, Pasupuleti M, Kotha AK, Reddanna P. The paradox of Akt-mTOR interactions. Front Oncol (2013) 3:165. doi:10.3389/fonc.2013. 00165

7. Vadlakonda L, Pasupuleti M, Reddanna P. Role of PI3K-Akt-mTOR and Wnt signaling pathways in G1-S transition of cell cycle in cancer cells. Front Oncol (2013) 3:85. doi:10.3389/fonc.2013.00085

8. Pardo OE, Seckl MJ. S6K2: the neglected S6 kinase family member. Front Oncol (2013) 3:191. doi:10.3389/fonc.2013.00191

9. Porta C, Paglino C, Mosca A. Targeting PI3K/Akt/mTOR signaling in cancer. Front Oncol (2014) 4:64. doi:10.3389/fonc.2014.00064

10. Weigelt B, Downward J. Genomic determinants of PI3K pathway inhibitor response in cancer. Front Oncol (2012) 2:109. doi:10.3389/fonc.2012.00109

11. Fox EM, Arteaga CL, Miller TW. Abrogating endocrine resistance by targeting ER alpha and PI3K in breast cancer. Front Oncol (2012) 2:doi:10.3389/fonc. 2012.00145

Conflict of Interest Statement: The author declares that the research was conducted in the absence of any commercial or financial relationships that could be construed as a potential conflict of interest.

Received: 19 March 2014; accepted: 05 April 2014; published online: 22 April 2014. Citation: Arcaro A (2014) Targeting PI3K/mTOR signaling in cancer. Front. Oncol. 4:84. doi: $10.3389 /$ fonc.2014.00084

This article was submitted to Molecular and Cellular Oncology, a section of the journal Frontiers in Oncology.

Copyright $\odot 2014$ Arcaro. This is an open-access article distributed under the terms of the Creative Commons Attribution License (CC BY). The use, distribution or reproduction in other forums is permitted, provided the original author(s) or licensor are credited and that the original publication in this journal is cited, in accordance with accepted academic practice. No use, distribution or reproduction is permitted which does not comply with these terms. 